\title{
Mysticism and/in the Old Testament: Methodological orientation and a textual example
}

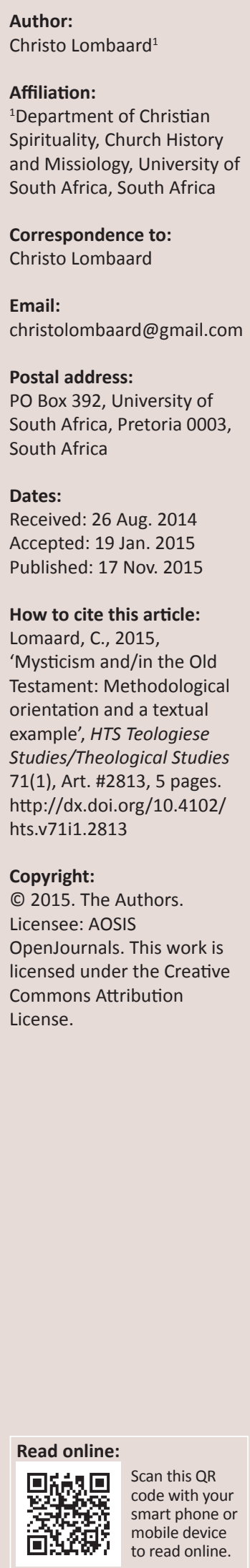

This contribution is the second in a series on methodology and Biblical Spirituality. In the first article, 'Biblical spirituality and interdisciplinarity: The discipline at cross-methodological intersection', the matter was explored in relationship to the broader academic discipline of Spirituality. In this contribution, the focus is narrowed to the more specific aspect of mysticism within Spirituality Studies. It is not rare for Old Testament texts to be understood in relationship to mystical contexts. On the one hand, when Old Testament texts are interpreted from a mystical perspective, the methods with which such interpretations are studied are familiar. The same holds true, on the other hand, if texts in the Old Testament, dating from the Hellenistic period, are identified as mystic. However, African mission history has taught us that the Western interpretative framework, based on ancient Greek philosophical suppositions (most directly the concepts rendered by Plato and Aristotle) and rhetorical orientations, is so strong that it transposes that which it encounters in other cultures into its terms, thus rendering the initial cultural understandings inaccessible. This is precisely the case too with Old Testament texts dating from pre-Hellenistic times, identified as mystic. What are the methodological parameters required to understand such texts on their own terms? In fact, is such an understanding even possible?

\section{'It's all Greek to me': On breadcrumbs, African mission analogy and non-material interculturality}

That there is a centuries-long tradition of connecting the Hebrew Bible and mysticism requires little elucidation. This can be illustrated with just a few examples such as Merkabah mysticism and Kabbalah mysticism with the Zohar from Jewish circles, which have their antecedents as far back as Qumran (cf. e.g. Thomas 2009:3-15, with particular emphasis on mystery). Another example is the fourfold senses based on the lectio Divina with which the Old Testament was read within Christianity (cf. Cousins 2000:118-137). In these and other experiences of faith related to the Hebrew Bible or Old Testament, one does not encounter spirituality-as-usual where the ordinary is related to the Bible (on the Bible and spirituality, see foundationally Schneiders 1985:1-20, also Lombaard 2012; on the discipline of Biblical Spirituality, see Welzen 2011:37-60). Mysticism as spirituality unusual relates to peak religious experiences (cf. Kourie 2011:136-138; Perrin 2005:443, 449-451; Minnaar [2000:7-54] gives an overview of the concept of mysticism) in which 'unity' ${ }^{1}$ with God is amongst the favoured ways through which to express the ecstasy of an experienced encounter with the Divine. ${ }^{2}$ Examples of these forms of mysticism to which authors have often referred since the early Christian tradition include the religious experiences of Paul in the New Testament (cf. e.g. Kourie 1998:441-448) and, later, the many figures and their elevated experiences related in the reviews of mysticism (cf. e.g. Joubert 2013; Krüger 2006; McGinn 2004). That the description of many of these experiences in the Christian tradition is drenched in Old Testament thematics, amongst others, is clear. In this regard, the book of Song of Songs is by no means the least amongst the texts to which authors alluded (cf. e.g. Perrin 2005:445). The latter should also be seen in interaction with the fact that, in the Christian church, the Song of Songs

1.Precisely what such "unity" would entail remains an open category, as formulated in Lombaard (2013:2-3): "[U]nity with the divine has in the Christian and other mystical streams been an important, deeply existential topos. Within a conceivable matrix of possibilities here would lie the ideals of the disappearance-of-being, when the individual is subsumed within the holy, as we find it in the idea of nirvana in Hinduism and related faith expressions, where a unity-into-nothingness with the divine is regarded as the ultimate "heaven". Another point on such a matrix would be existentially to lose oneself within humanity, with such an utter identification of the self with the plight of the "neighbour", near and far, that we are only therein. On a different point would lie Tillich's God-beyond-(only-our-)existence, yet precisely therefore involved with humanity (e.g. Tillich 1951-1963). Moreover, within the Christian spiritual tradition there has for long been the unresolved, and often unreflected upon, tension of what "unity with God" would mean: is it such an all-engaging encounter of ultimate intimacy with the divine that one finds oneself taken up into God "would mean: is it such an all-engaging encounter of ultimate intimacy with the divine that one finds oneself taken up into the Godhead, or is it a closeness to God in which I seem to lose myself so fully that the only possible metaphor is "to be one with God", though then not equalling the ontological intensity of the Trinity, or the human becoming dive, or similar expressions? Then where within this matrix would one find the idea, so common in Afrikaans [popular] piety, and pietism, "om soos Jesus te wees"
["to be like Jesus"]?'

2.The concept of the 'Divine' or 'God' is also a contentious matter, with the debate now traversing the borders of the ontological and the epistemological. Within the discipline of Spirituality, a decision on where researchers would situate themselves within this debate is not required in a context such as this since the experience of the Divine or God, in whichever form it may be thought to be, on the part of whomever has a religious encounter, is paramount. 
had become the most commented upon book in the Bible and always in spiritualised fashion (for a theory on why this could be, cf. Lombaard in press). ${ }^{3}$

There is thus no problem with historically identifying the relationship between mysticism and the Old Testament: The former clearly draws on the latter in its expression. To identify such Old Testament influence and then to analyse it seems to present no more than the usual methodological challenges that hold for historical, literary or phenomenological analyses. Though the mystic encounter itself (Thomas 2009:1-2) and the Divine 'involved' in such an encounter lie outside of the parameters of scholarship as it is understood in our time, the reports on these events (cf. Kourie 1992:92) are easier game: As Cupitt (1998:60) argues, all mysticism is written. Although I disagree with the point in that there is clearly more to the mystic encounter than just the text(s) in its wake (Lombaard 2014:484; cf. Budriunaite 2013:4), it remains valid that these writings are traces (to employ a concept from Derrida [1976]) - that is all we have of the mystic and the mystic encounter. We have the breadcrumbs of what is not (cf. Kourie 2008:59-75), and these breadcrumbs are concrete enough for historicalphenomenological study (a post-secular point: cf. Lombaard 2015), the more so given that all mystical experiences are contextually anchored (Budriunaite 2013:14-18; Katz 2000:17-18; Kourie 1992:96-99).

However, can the same be said of mysticism in the Old Testament: that the methodology is as per usual? Is the difference of interculturality between the ancient NearEastern world with its religio-cultural make-up and ours ${ }^{4}$ not so vast that it becomes well-nigh impossible to come to a historical-contextually authentic understanding of what mysticism may have been in such an 'other' life or faith world?

In this respect, the Old Testament life or faith world is not unique and therefore the analogy of Africa's mission experience may well be instructive for our case here. Although the sometimes one-sided, negative view in recent decades that followed on the sometimes highly romanticised view of the role of missionaries from Europe in Africa is itself recently being tempered by more balanced critical evaluation, it is clear that the intercultural and interreligious contact between the West and Africa followed a fairly typical pattern. Just as the translation of the Hebrew Bible into Greek fundamentally altered certain key concepts, so the Christian-Roman 'civilisation' altered the 'barbarian' mind with which it came in contact. For instance, in Germanic Europe and also in Africa, later, when missionaries from Europe engaged with their African converts-to-be, the

3. Exploring the interaction between Song of Songs and spirituality seems to be in vogue at present with two recent South African Master's degrees (Lam 2012; Oosthuizen 2014) exploring this avenue, both in fresh ways and in the German language contex with Schwienhorst-Schonberger (2015) now, controversially, engaged in indicatin 2008:389-395)

4.By 'ours' is meant the kind of Western(ised) thought worlds occupied by people touched by the mindsets of science and human rights, differently, but still in many ways typical of the era in which we live under Western(ised) cultural hegemony. 'receiving' culture was altered in its material goods as much as in its non-material goods of 'values, beliefs, norms, traditions' (Gutman 2010:215 - a distinction which must be regarded as a soft division; cf. Pfaffenberger 2004:62; Slater 2004:190-192). Leaving aside the former for the moment, the 'conceptualature' of African culture had, as one instance amongst many in history, been transformed in its meeting with Western culture. This, for instance, led to the more powerful, 'imparting' culture giving (new) language to phenomena and aspects of the receiving culture with the latter adopting the conveyed nomenclature unwittingly, at least to some extent. Furthermore, the receiving culture irrevocably ${ }^{5}$ stepped over the threshold into the intellectual household of the more powerful imparting culture (cf. e.g. Mothoagae [2014:1-12] for a description of this phenomenon, at times shockingly extreme to current sensibilities, in the South-African mission history). This (South) African experience does not only illustrate the power of one ancient cultural stream that is to some extent conceptually engulfed in another. It also demonstrates how, even in the subsequent reactions to this, 'the two veteran African theologies, namely those of inculturation and liberation' (Munga 2000:245) remain linked to such earlier intercultural and interreligious tectonics.

To return again to the beginning of this broad historical sweep, I now have to apply the analogy from (South) African mission history: A pattern of influence similar to that of the (South) African mission history occurred in ancient Judean society in the centuries immediately preceding the Christian era. It must be kept in mind that the later texts of the Old Testament, certainly those that had come into being after the beginning of the Alexandrian conquest of Judea in 332 $\mathrm{BCE}$, were still in the process of being edited. Some of these, most noticeably Ecclesiastes (Lohfink 2003), were influenced by the ancient Greek thought world. In these texts, the diverse cultural backgrounds can be indicated. Some scholars, particularly those who have become known as the Copenhagen school or minimalist group of Old Testament historiographers (cf. e.g. Lemche 2008), regard (almost) all of the Old Testament as having originated close to or during the Hellenistic period. More recently and less radically, Levin (2013) characterised $90 \%$ of Old Testament texts as postexilic, which means after 538 BCE. This leaves two centuries, albeit the most productive literary and theologicallydiscursive centuries in ancient Israel's history, which can at least in some broad sense be described as pre-Hellenistic, thus with the ancient Near-Eastern religio-cultural context still as primarily formative of the life or faith world in which Old Testament traditions and texts were being created and further developed.

5.I remain pessimistic that the lost conceptualature can be regained in cultures that had not had a tradition of documentation. Even in the case of ancient Israel, for instance, recapturing from its bequeathed texts an authentic faith or life world is hampered both by the usual problems of historiography and by the fact that these hampered both by the usual problems of historiography and by the fact that these analyses are done from outside that culture: Can such an 'other' culture ever truly be 'entered' to understand it? Moreover, how would we know if we did so with some accuracy? At best, self-critical approximations are possible, but still only on the terms of the imparting and dominating culture. (This characterises to some extent the whole enterprise of Bible exegesis!) With oral cultures, these same problems are compounded exponentially, given the various vagaries to which oral histories are subject. 
Clearly, by the time mystic language became prominent in Qumran and further, the Hellenistic thought world had, at least in this respect, influenced or even determined the ancient Near-Eastern thought world substantially. Thus a cultural stream was formed from which it has been difficult to retreat in the history of the Western(ised) world. ${ }^{6}$ This 'Greek' thinking ${ }^{7}$ is strong enough in its self-critical dimensions to realise and analyse its dominance. However, even in doing so, we are trapped within it as in a maze ${ }^{8}$. It can give the deep comfort of existential meaning, but can one ever leave?

Returning to the distinction between mysticism and the Old Testament as opposed to mysticism in the Old Testament, the following can be noted:

- Analysing the former from within this (= its own) culture stream provides no extraordinary methodological concerns (cf. England 2011:65). The way in which, through the Christian ages, the church fathers and mothers and the mystics appropriated, for instance, Song of Songs in their reports of mystical encounters provides less and mostly known (intercultural) barriers (cf. Waaijman 2011:1-2, 18). All of this occurred in the same 'Greek' cultural stream in which we find ourselves.

- The same would to some extent also apply to mysticism in the Old Testament if the texts concerned were conceived or substantially completed within the Hellenistic period.

However, the methodological question related to mysticism in the older Old Testament texts is (cf. Pohlig 2003:21-25): What are the additional barriers of interculturality which will have to be crossed in order, with greater validity, to speak of mysticism in the ancient, non-'Greek' faith or life world of ancient Israel?

This becomes a weightier concern if one endeavours to understand a pre-Hellenistic Old Testament text on its own terms rather than ours - as we should. ${ }^{9}$ The current slow turn to an interest in mystical readings of Old Testament texts does not mean that the moves in modernist and postmodernist ${ }^{10}$ scholarship are now to be circumvented (cf. Kourie 2011:132-133, 136). Rather, current scholarship has

6.This is for instance also the case with the concept of the "soul'.

7.'Greek' here is meant as a shorthand expression for the ancient Greek philosophical, rhetorical and language system, which has, because of political-historical reasons but also on the strength of its own dynamism, substantially influenced all three Book Religions and all cultures which it has touched. Though undergoing changes Book Religions and all cultures which it has touched. Though undergoing changes
through the ages, this 'Greek' thinking still provides the general philosophical and through the ages, this 'Greek' thinking still provides the general philosophical and
logical underpinnings on which all Western(ised) societies function. To employ an analogy from computer programming: The operating system is all 'Greek', and all analogy from computer programming: The operating system is all 'Greek', and all
software that runs on it must, in order to be compatible, defer to its precepts. (This is not meant as either a negative or a positive evaluation but merely as an observation. Though the process of interculturality is of course much more complex than described here, encompassing for instance mutual influence and creative cultural neologisms, the point intended here is that the usurping power of the dominant culture ought to be realised.)

8.Or as in the folk rock band the Eagles' song, 'Hotel California'.

9.Even though the alternative - to simply transport the ancient text into our world would seem so much simpler because it renders 'results' much more easily.

10.By modernism is meant the kind of rationalism most directly proposed by Descartes and Kant in which the metaphysical has little place in day-to-day living and which finds its strongest expression within scholarship in logical positivism. By postmodernism is meant the reaction to modernism, in which the firmness of By postmodernism is meant the reaction to modernism, in which the firmness of
knowledge and understanding are called into question, with Derrida as the most knowledge and understanding are called into question, with
well-known exponent of this more relational kind of thinking. to build on these efforts: Now, what is required is not less, but more. Typical of the world of post-secularism towards which Christianity is currently unevenly edging, past religio-cultural 'phases' (cf. Taylor 2007; also Lombaard 2015; Nynäs, Lassander \& Utriainen 2012) are not nullified, but reflected upon anew. They are perhaps reflected upon anew, perhaps askew, but then precisely because past labours are being incorporated: The exegesis of a mystical text becomes more comprehensive, more involved than before. These include, for instance, the following:

- In our time, many clearly yearn for the implicit faith of pre-modernism as something that would touch the heart for the very reason that it touches the ground.

- The thoroughly historical insights of modernist scholarship dare not be foregone, specifically because of the unsettling existential lucidity and dignified intellectual integrity which they provide.

- We ought to consider the humbling corrective rendered to us by post-modernism concerning the flawed optimisms of the modernist enterprise, with post-modernism's insistence on relationality and its distrust of rationality. At the same time, we have to employ the latter while dismantling the former, thus (unwittingly) preparing the ground for the mystic none and the mystic all that engages us here.

What does this mean for the reading of a text?

\section{'It's all God-to-me': Psalm 1, from 'old mystically' read to 'new mystically' read}

Psalm 1 would suit well the purposes of illustrating the above. It is a Psalm that historically predates the later, more strongly Hellenistically influenced Judean faith or life world. It is a text that has been used in older forms of mystical readings, thus rendering us sufficient comparative material. However, it is not one of the more popular such texts from the Old Testament (which includes the Genesis creation chapters, the Moses theophanies, the Isaiah visions, Song of Songs, the opening chapter of Ezekiel and Noah's ark; cf. Katz 2000:8-10). It is of manageable proportions for an endeavour such as this, with all too limited scope (so that here all points have to be made only by means of summary). Furthermore, Psalm 1 has been thoroughly studied during all socio-religious 'phases' through which Western(ised) societies have passed. It is, lastly, a Psalm which I have very recently attempted - in a deliberately post-secular move - to read from faith, for faith, as a text in which the voice of the Divine may be experienced. My reading was not based on pious pre-commitments but most directly on fully historical exegetical concerns, drawing throughout on what may be characterised as previously published modernist and postmodernist exegetical endeavours (Lombaard 2014:472-488) (see Table 1).

Although mystical readings of Psalms are by no means something of the past (cf. the well-considered Waaijman [2004] 
TABLE 1: Psalm 1 - Text and translation.

\begin{tabular}{|c|c|}
\hline Psalm 1 & NRSV Translation \\
\hline 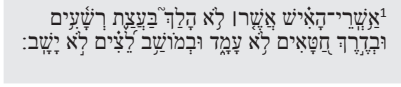 & $\begin{array}{l}{ }^{1} \text { Happy are those who do not follow the } \\
\text { advice of the wicked, or take the path that } \\
\text { sinners tread, or sit in the seat of scoffers; }\end{array}$ \\
\hline 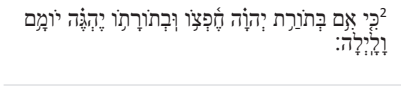 & $\begin{array}{l}{ }^{2} \text { but their delight is in the law of the } \\
\text { LORD, and on his law they meditate day } \\
\text { and night. }\end{array}$ \\
\hline \multirow[t]{2}{*}{ 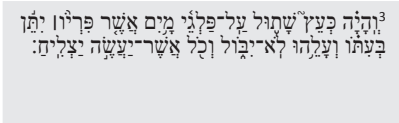 } & $\begin{array}{l}{ }^{3} \text { They are like trees planted by streams of } \\
\text { water, which yield their fruit in its season, } \\
\text { and their leaves do not wither. }\end{array}$ \\
\hline & In all that they do, they prosper. \\
\hline 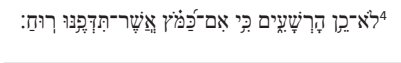 & $\begin{array}{l}{ }^{4} \text { The wicked are not so, but are like chaff } \\
\text { that the wind drives away. }\end{array}$ \\
\hline 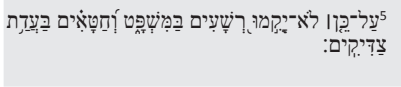 & $\begin{array}{l}{ }^{5} \text { Therefore the wicked will not stand in the } \\
\text { judgment, nor sinners in the congregation } \\
\text { of the righteous; }\end{array}$ \\
\hline 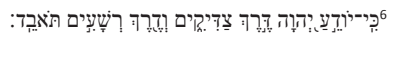 & $\begin{array}{l}{ }^{6} \text { for the LORD watches over the way of } \\
\text { the righteous, but the way of the wicked } \\
\text { will perish. }\end{array}$ \\
\hline
\end{tabular}

and the limited circulation DePrince [1993]), the emphasis here is on ancient readings, ${ }^{11}$ specifically the mystical reading of Psalm 1 by the late 4th-century monk in Egypt, Evagrius Ponticus (cf.e.g. Casiday [2006] on his lifeand works). Evagrius understands Psalm 1 (cf. Gillingham 2013:54-55) as the words of King David under the guidance of the Holy Spirit. These words are meant for the ears of monks, though, with the first half of the Psalm meant to strengthen their contemplation. David here blesses the Egyptian desert monks. The curse of the second half of this Psalm is then a mystical conversion of the monks' suffering ascetic bodies into something heavenly, as God transforms them.

This is clearly a pre-modern reading of the Psalm with no interest in the real historical background to or the composition of the text. Of primary importance is the relationship with God with the intent that this would increase in intimacy to the point that God touches the body to heal it in holiness.

A modern reading, in contrast, takes the historical aspects of the text that have thus far been neglected as primary concern. The authorship can hardly be Davidic, and the genre indication of a blessing-curse Psalm is given prominence (cf. e.g. Gunkel 1986:1; Mowinckel 2004:xxxii). The thematic link with Psalms 19 and 119 as fellow Torah-Psalms become important (e.g. Botha 2012:1-7), and though aspects of faith are identified within ancient Israel in this way, next to this historical indication the importance thereof for the modern reader is given scant attention.

Although the latter may be reacted against by post-modern readings, at times expressly, related to Psalm 1 with specific attention to structure given that the emphasis is now on the text (e.g. Auffret 2001:156-165; Botha 1991:381-396; Richter 1971), the result is no improvement with respect to religious experientiality. Whereas, in modernism, the prime category of understanding is history, in post-modernism that category is language, and language has as little ability as history, in itself, to elicit an experience of faith on the part of the Bible reader.

11.Gillingham (2013:10-61) gives an overview of mystical and spiritual-pastora readings of Psalm 1 amongst the church fathers.
Such an experience of faith is, however, a main focus of the discipline of Spirituality as a post-secular development. This means that the sub-discipline of Biblical Spirituality seeks to retrace historically the impulses of faith that found their way into the text. It also seeks phenomenologically to relate the faith experience of readers of the Psalm to these ancient impulses of faith. This re/constructed relationality proves to be exegetically fruitful (Lombaard 2014:472-488) in that the historical impulse that most directly gives rise to this Psalm is the nascence of Torah theology in early post-exilic Israel in opposition to competing theological strands. Torah theology in post-exilic Israel seeks to mediate the experience of the Divine via a holy book rather than through, for instance, prophetic revelation. This is an orientation towards spirituality that has been influential to this day. The emphasis for many individuals and in many church traditions is still on Scripture reading in the encounter of believers with God as they seek to experience the Holy.

The last five paragraphs - all too briefly, yet for illustrative purposes clearly enough - indicate the reflex emphases brought forth in the religio-cultural 'phase' within which exegetes may find themselves. Important to note here is that the last rendering returns to the first in that it seeks to elicit on the part of the intended reader some kind of relationship with the Divine. However, this is not done by circumventing the impulses from modernism and post-modernism (that means, the impulses from historical-critical and structuralist analyses) but by drawing directly on these, though with the intent of seeing more in the text and delivering more to the readership: the experience of faith.

Now to turn to the questions ${ }^{12}$ from the maze. I have read this pre-Hellenistic text from an (albeit informed) post-secularist, religio-cultural stance, which is avowedly an outflow of the ancient 'Greek' thought world that has been the bedrock of the Western(ised) world over millennia. Against this background, when Psalm 1 is read as a text with (at least) mystic possibilities, it leads to the following questions:

- What am I missing?

- What have I unwittingly read into it?

- Can these questions at all be answered?

\section{Acknowledgements Competing interests}

The author declares that he has no financial or personal relationship(s) that may have inappropriately influenced him in writing this article.

\section{References}

Auffret, P., 2001, 'Comme un arbre ... Etude structurelle du Psaume 1', Biblische Zeitschrift 45(2), 256-264.

12.Lest the purpose of this article be misunderstood: the task set for this contribution is not to answer these questions, but to build the logic towards them. A next is not to answer these questions, but to build the logic towards them. A next satisfying way, without giving up: (1) the protocols of scholarship as understood within university contexts; (2) the limitations of our culturally determined human existence; or (3) the nature of mysticism, which transcends 1 and 2 in this list, though still being fathomable within both. 
Botha, P.J., 1991, 'The junction of the two ways: The structure and theology of Psalm 1', Old Testament Essays 4, 381-396.

Botha, P.J., 2012, 'Interpreting 'Torah' in Psalm 1 in the light of Psalm 119', HTS Teologiese Studies/HTS Theological Studies 68(1), 7 pages. http://dx.doi. org $/ 10.4102 /$ hts.v68i1.1274

Budriunaite, A., 2013, 'Investigation into mysticism: Limits and possibilities', in J.L. Hochheimer \& W.S. Schmidt (eds.), Spirituality in the 21st century: Explorations, pp. 39-62, Inter-Disciplinary Press, Oxford.

Casiday, A.M., 2006, Evagrius Ponticus, Routledge, London.

Cousins, E., 2000, 'The fourfold senses of scripture in Christian mysticism', in S.T. Katz (ed.), Mysticism and sacred scripture, pp. 118-137, Oxford University Press, Oxford.

Cupitt, C., 1998, Mysticism after modernity, Blackwell Publishers, Oxford.

DePrince, T., 1993, The mystical key to the Psalms, United Spiritual Temple, New York, NY.

Derrida, J., 1976, Of grammatology, Johns Hopkins University Press, Baltimore, MD.

England, F., 2011, 'Sacred texts and mystic meaning: An inquiry into Christian spirituality and the interpretive use of the Bible', Acta Theologica 31(2), 47-71. $\mathrm{http}: / / \mathrm{dx}$.doi.org/10.4314/actat.v31i2.3

Gillingham, S., 2013, A journey of two Psalms: The reception of Psalms 1 \& 2 in Jewish \& Christian tradition, Oxford University Press, Oxford.

Gunkel, H., 1986, Die Psalmen, 5th edn., Vandenhoeck \& Rupprecht, Göttingen.

Gutman, R., 2010, Architecture from the outside in: Selected essays by Robert Gutman, Princeton Architectural Press, New York, NY.

Joubert, L., 2013, Ontmoeting met heiliges: Verhale van hoe mense hulle geloof geleef het, Naledi, Kaapstad.

Katz, S.T., 2000, 'Mysticism and the interpretation of sacred scripture', in S.T. Katz (ed.), Mysticism and sacred scripture, pp. 7-67, Oxford University Press, Oxford.

Kourie, C., 1992, 'Mysticism: A survey of recent issues', Journal for the Study of Religion 5(2), 83-103.

Kourie, C., 1998, 'Mysticism: Gift for the church', Neotestamentica 32(2), 433-455.

Kourie, C., 2008, 'Mysticism: A way of unknowing', in P.G.R. de Villiers, C.E.T. Kourie \& C. Lombaard (eds.), The spirit that empowers: Perspectives on spirituality, Acta Theologica Supplementum 11, pp. 59-75, University of the Free State Press, Bloemfontein.

Kourie, C., 2011, 'Reading Scripture through a mystical lens', Acta Theologica 31, 132 153. http://dx.doi.org/10.4314/actat.v31i1S.8

Krüger, K., 2006, Sounding unsound: Orientation into mysticism, Aurora Press, Pretoria.

Lam, J.E., 2012, 'The Canticle of spiritual direction: A transformative approach to the Song of Songs', MTh dissertation, Dept. of Christian Spirituality, University of South Africa.

Lemche, N.-P., 2008, The Old Testament between theology and history: A critical survey, Westminster John Knox Press, Louisville, KY.

Levin, C., 2013, 'Die Entstehung des Judentums als Gegenstand der alttestamentlichen Wissenschaft', Presidential address at the 21st congress of the International Organisation for the Study of the Old Testament, Munich, 04-09 August.

Lohfink, N., 2003, Qoheleth: A continental commentary, Fortress Press, Minneapolis, $\mathrm{MN}$.

Lombaard, C., 2012, The Old Testament and Christian spirituality: Theoretical and practical essays from a South African perspective, Society of Biblical Literature, Atlanta, GA. (International Voices in Biblical Studies 2).

Lombaard, C., 2013, 'Let's get together and feel all right' (Bob Marley - 'One Love'): A response to Prof. DG van der Merwe', viewed 10 August 2013, from http://hdl. handle.net/10500/13541
Lombaard, C., 2014, 'Mysticism and understanding: Murmurs of meaning (fulness) Unheard silences of Psalm 1', Old Testament Essays 27(2), 472-488.

Lombaard, C. (in press), 'The sublime and the divine: God, eros and the poetic in Song of Songs and spiritual writings', Journal for Semitics/Tydskrif vir Semitistiek, forthcoming.

Lombaard, C., 2015, “'And never the twain shall meet?": Post-secularism as newly unfolding religio-cultural phase and Wisdom as ancient Israelite phenomenon: Spiritualities and implications compared and contrasted', Journal of Theology for Southern Africa 152, 82-95.

McGinn, B., 2004, The foundations of mysticism: Origins to the fifth century, Crossroad, New York, NY. (The Presence of God: A History of Western Christian Mysticism, vol. 1, paperback edn.).

Minnaar, C.L.K., 2000, 'n Filosofiese verantwoording van mistiek', MA-verhandeling, Dept. Filosofie, Universiteit van Pretoria.

Mothoagae, D.I., 2014, 'An exercise of power as epistemic racism and privilege: The subversion of Tswana identity', Souls: A Critical Journal of Black Politics, Culture, and Society 16, 1-2, 11-27. http://dx.doi.org/10.1080/10999949.2014.931085

Mowinckel, S., 2004, The Psalms in Israel's worship, Wm B. Eerdmans Publishing Co., Grand Rapids, MI.

Munga, S., 2000, 'Encountering changes in African theology', Swedish Missiological Themes 88(2), 225-250.

Nynäs, P., Lassander, M. \& Utriainen, T. (eds.), 2012, Post-secular society, Transaction Publishers, New Brunswick.

Oosthuizen, M., 2014, 'Reading Song of Songs as wisdom literature: An interpretative approach integrating sexuality and spirituality', MTh dissertation, Dept. of Old Testament, University of the Free State.

Perrin, D.B., 2005, 'Mysticism', in A. Holder (ed.), The Blackwell companion to Christian spirituality, pp. 442-458, Blackwell Publishing, Malden, MA.

Pfaffenberger, B., 2004, 'The social anthropology of technology', in V. Buchli (ed.), Critical concepts in social sciences, pp. 61-89, Routledge, London.

Pohlig, J.N., 2003, 'Cognition and biblical documents: Towards overcoming theoretical and methodological obstacles to recovering cultural worldviews', Journal of Northwest Semitic Languages 29(1), 21-35.

Richter, W., 1971, Exegese als Literaturwissenschaft: Entwurf einer alttestamentliche Literaturtheorie und Methodologie, Vandenhoeck \& Ruprecht, Göttingen.

Schneiders, S.M., 1985, 'Scripture and spirituality', in B. McGinn, J. Meyendorff \& J. Leclerq (eds.), Christian spirituality: Origins to the twelfth century, pp. 1-20, SCM Press, London.

Schwienhorst-Schönberger, L., 2008, 'Das Hohelied', in E. Zenger (Hrsg.), Einleitung in das Alte Testament, 7 Auflage, pp. 389-395, Kohlhammer Verlag, Stuttgart.

Schwienhorst-Schönberger, L., 2015, Das Hohelied der Liebe, Herder, Freiburg.

Slater, D., 2004, 'New times?', in V. Buchli (ed.), Critical concepts in social sciences, pp. 172-207, Routledge, London.

Taylor, C., 2007, A secular age, Harvard University Press, Cambridge, MA.

Thomas, S.I., 2009, The 'mysteries' of Qumran: Mystery, secrecy, and esotericism in the Dead Sea Scrolls, Society of Biblical Literature, Atlanta, GA.

Tillich, P., 1951-1963, Systematic theology, vol. 1, 2 \& 3, University of Chicago, Chicago, IL.

Waaijman, K., 2004, Mystiek in de Psalmen, Ten Have, Baarn.

Waaijman, K., 2011, 'Biblical spirituality: An "other" reading (allègoria)', in P.G.R. de Villiers \& L.K. Pietersen (eds.), The Spirit that inspires: Perspectives on Biblical spirituality, pp. 1-20, University of the Free State Press, Bloemfontein. (Acta Theologica Supplementum 15).

Welzen, H., 2011, 'Contours of Biblical spirituality as a discipline', in P.G.R. de Villiers \& L.K. Pietersen (eds.), The Spirit that inspires: Perspectives on Biblical spirituality, pp. 37-60, University of the Free State Press, Bloemfontein. (Acta Theologica Supplementum 15). 